\begin{tabular}{|c|c|} 
Jurnal Ayurveda Medistra \\
ISSN. 2656-3142| Volume 3 Nomor 2 | Agustus 2021 | pages:25-27 \\
Avalaible online at http://ojs.stikesmedistra-indonesia.ac.id/
\end{tabular}

\title{
Kajian Literatur : Terapi Nonfarmakologis Terhadap Kualitas Tidur Pada Lansia
}

\author{
Lisna Agustina
}

\author{
Program Studi Keperawatan Sekolah Tinggi IImu Kesehatan Ichsan Medical Centre Bintaro. \\ (lisna.agustina01@gmail.com) 085323817966
}

\begin{abstract}
Abstrak
Lansia merupakan istilah bagi individu yang telah memasuki periode dewasa akhir atau usia tua. Periode ini merupakan periode penutup bagi rentang kehiduoan seseorang, dimana telah terjadi kemunduran fisik dan psikologis secara bertahap. Salah satu aspek utama bagi dari peningkatan kesehatan untuk lansia adalah pemeliharaan tidur untuk memastikan pemulihan fungsi tubuh sampai tingkat fungsional yang optimal dan untuk menyelesaikan tugas-tugas dan menikmati kualitas hidup yang tinggi. Tujuan penelitian ini adalah untuk mengetahui efektifitas terapi non farmakologis terhadap peningkatan kualitas tidur lansia yang memiliki gangguan tidur baik dengan atau tanpa sakit. Metodologi yang digunakan adalah dengan melakukan penelusuran literatur atau kajian literatur dengan menggunakan databased elektronik melalui internet yaitu google scholar dan jurnal elektronik lainnya dengan kata kunci lansia, kualitas tidur dan terapi nonfarmakologis. Literature review mengkaji 10 artikel terkait, didapatkan hasil bahwa terapi nonfarmakologis signifikan meningkatkan kualitas tidur pada lansia yang memiliki gangguan tidur. Terapi nonfarmakologis menjadi pilihan pengobatan komplementer untuk lansia dengan gangguan tidur.

Abstract

Elderly is a term for individuals who have entered the period of late adulthood or old age. This period is the closing period for a person's life span, where there has been a gradual physical and psychological setback. One of the main aspects of improving health for the elderly is the maintenance of sleep to ensure the restoration of bodily functions to an optimal functional level and to complete tasks and enjoy a high quality of life. The purpose of this study was to determine the effectiveness of non-pharmacological therapies to improve sleep quality in the elderly who have sleep disorders both with and without illness. The methodology used is to search literature or study literature using electronic databased via the internet, namely google scholar and other electronic journals with the keywords elderly, sleep quality and nonpharmacological therapy. Literature review examines 10 related articles, found that nonpharmacological therapy significantly improves sleep quality in the elderly who have sleep disorders. Nonpharmacologic therapy is a complementary treatment option for the elderly with sleep disorders
\end{abstract}




\section{PENDAHULUAN}

Lanjut usia adalah bagian dari proses tumbuh kembang. Manusia tidak secara tiba-tiba menjadi tua, tetapi berkembang dari bayi, anak-anak, dewasa dan akhirnya menjadi tua. Hal ini normal, dengan perubahan fisik dan tingkah laku yang dapat diramalkan yang terjadi pada semua orang pada saat mereka mencapai usia tahap perkembangan kronologis tertentu. Lansia merupakan suatu proses alami yang ditentukan oleh Tuhan Yang Maha Esa. Semua orang akan mengalami proses menjadi tua dan masa tua merupakan masa hidup manusia yang terakhir. Dimasa ini seseorang mengalami kemunduran fisik, mental dan social secara bertahap. Lansia juga dapat diartikan sebagai individu yang telah memasuki periode dewasa akhir atau usia tua. Periode ini merupakan periode penutup bagi rentang kehidupan seseorang, dimana telah terjadi kemunduran fisik dan psikologis secara bertahap. Salah satu aspek utama bagi dari peningkatan kesehatan untuk lansia adalah pemeliharaan tidur untuk memastikan pemulihan fungsi tubuh sampai tingkat fungsional yang optimal dan untuk menyelesaikan tugas-tugas dan menikmati kualitas hidup yang tinggi.

Berdasarkan data dari Biro Pusat Statistik (BPS) menunjukkan bahwa terjadi peningkatan jumlah lansia yaitu presentase lansia terhadap jumlah penduduk meningkat dari 9,27 \% pada tahun 2000 menjadi $10,57 \%$ pada tahun 2011 . Pada tahun 2020 jumlah lansia diperkirakan $11,34 \%$ dari jumlah penduduk (Badan Pusat Statistik, 2011). Pertambahan jumlah lansia di beberapa negara, salah satunya Indonesia, telah mengubah profil kependudukan baik nasional maupun dunia. Hasil sensus penduduk tahun 2010 menunjukkan bahwa jumlah penduduk lansia di Indonesia berjumlah 18,57 juta jiwa, meningkat sekitar 7,93 \% dari tahun 2000 yang sebanyak 14,44 juta jiwa. Diperkirakan jumlah penduduk lansia di Indonesia akan terus bertambah sekitar 450.000 jiwa per tahun. Dengan demikian, pada tahun 2025 jumlah penduduk lansia di Indonesia akan sekitar 43 juta jiwa (badan pusat statistik dalam Iriadi, 2012). Penelitian di Amerika Serikat mengidentifikasi bahwa $50 \%$ lansia yang tinggal di komunitas da $70 \%$ lansia yang tinggal di tempat perawatan mengeluhkan kualitas tidur mereka. $21 \%$ lansia di Indonesia mengalami gangguan dalam kualitas tidurnya. Umumnya hampir 1,5 kali lipat lebih banyak diderita orangtua dibanding anak muda (Wahyuni, 2019).

Kualitas tidur merupakan keadaan tidur yang dijalani seorang individu untuk menghasilkan kesegaran dan kebugaran saat terbangun. Kualitas tidur mencakup aspek kuantitaif dari tidur, seperti durasi tidur, latensi tidur serta aspek subjektif dari tidur. Kualitas tidur merupakan kemampuan setiap orang untuk mempertahankan keadaan tidur dan untuk mendapatkan tahap tidur rapid eye movemnet (REM) dan Non rapid eye movement (NREM) yang normal (Potter \& Perry, 2009). Menurut Ouellet (1995), kualitas tidur merupakan penilaian individu mengenai kenyenyakan tidur, persepsi tentang pergerakan selama tidur dan pengkajian umum dari kualitas tidur. Kualitas tidur yang baik diperlihatkan dengan mudahnya seseorang memulai tidur saat jam tidur, mempertahankan tidur, menginisiasi untuk tidur kembali setelah terbangun di malam hari, dan peralihan dari tidur ke bangun di pagi hari dengan mudah (LeBourgeois et al., 2005 cit. Saputri, 2014). Pengukuran kualitas tidur dapat diukur dengan menggunakan instrumen Pittsburgh Sleep Quality Index (PSQI) yang terdiri dari tujuh komponen, yaitu kualitas tidur secara subjektif, latensi tidur (durasi mulai dari berangkat tidur hingga tertidur), durasi tidur (dihitung dari waktu seseorang tidur sampai terbangun di pagi hari), efisiensi kebiasaan tidur (rasio persentase antara jumlah total jam tidur dibagi dengan jumlah jam yang dihabiskan di tempat tidur), gangguan tidur, disfungsi di siang hari, dan penggunaan obat yang mengandung sedatif.

Penggunaan obat-obatan yang mengandung sedatif mengindikasikan adanya masalah tidur. Obat-obatan mempunyai efek terhadap terganggunya tidur pada tahap REM. Oleh karena itu, setelah mengkonsumsi obat yang mengandung sedatif, seseorang akan dihadapkan pada kesulitan untuk tidur yang disertai dengan frekuensi terbangun di tengah malam dan kesulitan untuk kembali tertidur, semuanya akan berdampak langsung terhadap penurunan kualitas tidur (Buysse et al., 1989 cit. Modjod, 2017). Gangguan tidur merupakan hal yang sering dijumpai pada orang dewasa terutama lansia. Gangguan tidur adalah kondisi terputusnya tidur yang mana pola tidurbangun seseorang berubah dari pola kebiasaannya, hal ini menyebabkan 
penurunan baik kuantitas maupun kualitas tidur seseorang (Buysse et al., 1989 cit. Modjod, 2017). Gangguan tidur kronis dapat menyebabkan gangguan fungsional pada siang hari, rasa kantuk di siang hari, kelelahan, penurunan kualitas hidup, dan dapat meningkatkan kebutuhan perawatan kesehatan (Vitiello et al., 2009).Sebagian orang yang mengalami gangguan tidur memilih mengkonsumsi obat tidur dengan tujuan untuk meningkatkan kualitas tidurnya.Namun, apakah konsumsi obat tidur tersebut dapat meningkatkan kualitas tidur?

Metode penatalaksanaan yang bertujuan untuk meningkatkan kualitas tidur lansia pada umumnya dengan menggunakan terapi farmakologis, namun dengan pemakaian obat yang berlebihan akan berdampak bagi kesehatan lansia. Pemakaian obat-obatan inipun bila tidak disertai dengan perbaikan pola makan , pola tidur serta penyelesaian penyebab psikologis, maka obat-obatan hanya dapat mengatasi gangguan yang bersifat sementara dan tidak menyembuhkan. Dengan demikian diperlukan terapi nonfarmakologis yang efektif dan aman untuk meningkatkan kualitas tidur lansia.

\section{METODE PENELITIAN}

Metode penelitian yang digunakan dalam kajian literatur ini adalah dengan mengumpulkan dan menganalisa artikelartikel penelitian mengenai terapi nonfarmakologis terhadap kualitas tidur lansia. Artikel dikumpulkan dari databased elektronik melalui internet yaitu google scholar dan jurnal elektronik lainnya dengan kata kunci lansia, kualitas tidur dan terapi nonfarmakologis. Kriteria artikel yang digunakan adalah artikel yang diterbitkan pada kurun waktu 2010-2020. Pembahasan literatur ini meliputi : mengkaji efektivitas terapi nonfarmakologis terhadap kualitas tidur lansia.

\section{HASIL PENELITIAN}

Penelusuran literatur dilakukan
terhadap artikel penelitian yang berhubungan dengan terapi nonfarmakologis terhadap kualitas tidur lansia. Dari hasil penelusuran literatur sebanyak 9 buah artikel hasil penelitian diperoleh berbagai macam alternatif pilihan terapi nonfarmakologis yang berpengaruh terhadap peningkatan kualitas tidur lansia. Hasil penelitian tersebut yaitu terapi tawa, 2 artikel senam lansia, 2 artikel terapi dengan aroma lavender, terapi relaksasi benson, terapi musik klasik mozart, terapi musik jawa, terapi murotal Al-quran.

Dari artikel-artikel tersebut menunjukkan hasil bahwa semua terapi farmakologis memiliki dampak atau berpengaruh signifikan terhadap kualitas tidur lansia. Lansia yang diberikan terapi tersebut mengalami peningkatan kualitas tidur yang signifikan. Namun demikian, dalam artikel-artikel tersebut belum ada artikel yang meneliti perbandingan antara terapi yang satu dengan yang lainnya. Pemilihan terapi non farmakologis dapat disesuaikan dengan keadaan dan ketersediaan fasiltas yang ada.

Tabel 1 : Hasil Penelitian Lain Terkait Terapi Nonfarmakologis Untuk Meningkatkan Kualitas Tidur Pada Lansia

\begin{tabular}{|c|c|c|}
\hline $\begin{array}{l}\text { Peneliti, Judul, dan } \\
\text { Tahun Penelitian }\end{array}$ & Desain & Hasil Penelitian \\
\hline 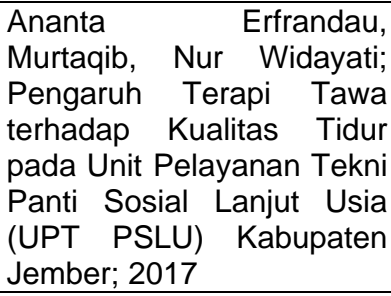 & $\begin{array}{l}\text { Desain penelitian randomized } \\
\text { pretest-posttest design }\end{array}$ & $\begin{array}{l}\text { Kualitas tidur diukur dengan mengunakan } \\
\text { Pittsburgh Sleep Quality Index (PSQI) } \\
\text { dan data dianalisis dengan t-test, Uji } \\
\text { Wilcoxon dan Uji Mann Whitney } \\
\text { didapatkan hasil perbedaan yang } \\
\text { signifikan dari kualitas tidur kelompok } \\
\text { lansia yang diberi perlakuan. }\end{array}$ \\
\hline 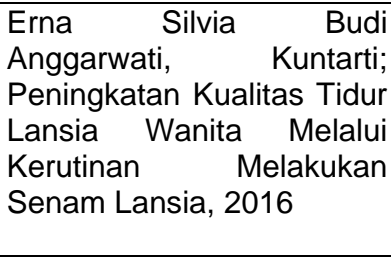 & $\begin{array}{l}\text { Desain penelitian dengan } \\
\text { pendekatan cross sectional }\end{array}$ & $\begin{array}{l}\text { Kualitas tidur diukur dengan mengunakan } \\
\text { Pittsburgh Sleep Quality Index (PSQI). } \\
\text { Data dianalisis dengan uji t-independen } \\
\text { dengan hasil menunjukkan ada } \\
\text { perbedaan skor PSQI lansia wanita yang } \\
\text { melakukan senam lansia dan yang tidak } \\
\text { melakukan senam lansia }\end{array}$ \\
\hline $\begin{array}{l}\text { Jefry Mahardika, Joni } \\
\text { Haryanto, Abu Bakar; } \\
\text { Hubungan } \quad \text { Keteraturan }\end{array}$ & $\begin{array}{l}\text { Desain penelitian dengan } \\
\text { pendekatan cross sectional }\end{array}$ & $\begin{array}{l}\text { Data dianalisis dengan menggunakan } \\
\text { Spearman Rank Correlation didapatkan } \\
\text { hasil bahwa lansia yang rutin mengikuti }\end{array}$ \\
\hline
\end{tabular}




\begin{tabular}{|c|c|c|}
\hline $\begin{array}{lrr}\text { Mengikuti Senam } & \text { Lansia } \\
\text { dan Kabutuhan } & \text { Tidur } \\
\text { Lansia di UOT } & \text { PSLU } \\
\text { Pasuruan di } & \text { Babat } \\
\text { Lamongan; 2015 } & \end{array}$ & & $\begin{array}{l}\text { senam lansia dapat meningkatkan } \\
\text { kebutuhan tidur lansia, artinya ada } \\
\text { hubungan antara senam lansia dengan } \\
\text { kebutuhan tidur lansia }\end{array}$ \\
\hline $\begin{array}{l}\text { Dian Sari, David Leonard; } \\
\text { Pengaruh Aromaterapi } \\
\text { Lavender terhadap Kualitas } \\
\text { Tidur Lansia di Wisma } \\
\text { Cinta Kasih; } 2017\end{array}$ & $\begin{array}{l}\text { Desain penelitian dengan } \\
\text { preeksperimental } \\
\text { menggunakan rancangan one } \\
\text { group pretest-posttest design }\end{array}$ & $\begin{array}{l}\text { Data dianalisis dengan Uji T-test } \\
\text { didapatkan hasil dari } 100 \% \text { lansia yang } \\
\text { mengalami kualitas tidur buruk, setelah } \\
\text { diberikan aromaterapi kualitas tidur } \\
\text { menjadi meningkat, berarti ada pengaruh } \\
\text { pemberian aromaterapi lavender dengan } \\
\text { kualitas tidur lansia }\end{array}$ \\
\hline $\begin{array}{l}\text { Dini Sukmalara; } \\
\text { Evidenerapan } \\
\text { Aromaterapi Practice } \\
\text { Lavender Pada Lansia } \\
\text { Dengan Insomnia di } \\
\text { Sasana Tresna Wredha } \\
\text { (STW) Karya Bakti Cibubur } \\
\text { Tahun 2017; } 2017\end{array}$ & $\begin{array}{l}\text { Desain } \\
\text { eksperimental semu dengan } \\
\text { rancangan one group pretest- } \\
\text { postetest design }\end{array}$ & $\begin{array}{l}\text { Hasil penelitian diperoleh bahwa setelah } \\
\text { diberikan perlakuan aromaterapi } \\
\text { lavender terjadi peningkatan kualitas tidur } \\
\text { pada lansia, artinya aromaterapi bunga } \\
\text { lavender memberikan pengaruh yang } \\
\text { signifikan terhadap kualitas tidur lansia }\end{array}$ \\
\hline $\begin{array}{l}\text { Handono Fatkhur Rahman, } \\
\text { Ririn Handayani, Baitus } \\
\text { Sholahah; Pengaruh Terapi } \\
\text { Relaksasi Benson terhadap } \\
\text { Kualitas Tidur Lansia di } \\
\text { UPT Pelayanan Sosial } \\
\text { Lanjut Usia Bondowoso; } \\
2019\end{array}$ & $\begin{array}{l}\text { Desain } \\
\text { eksperimental semu dengan } \\
\text { nonrandomized control group } \\
\text { pretest-posttest design }\end{array}$ & $\begin{array}{l}\text { Hasil penelitian menunjukkan bahwa } \\
\text { adanya pengaruh terapi relaksasi benson } \\
\text { terhadap kualitas tidur lansia pada } \\
\text { kelompok intervensi }\end{array}$ \\
\hline $\begin{array}{l}\text { Andrian Riska Sahanantya, } \\
\text { Yunie Armiyati, Syamsul } \\
\text { Arif; Pengaruh Terapi } \\
\text { Musik Klasik Mozart } \\
\text { terhadap Kualitas Tidur } \\
\text { pada Pasien Stroke di } \\
\text { Rumah Sakit Panti Wilasa } \\
\text { Citarum Semarang; 2014 }\end{array}$ & $\begin{array}{l}\text { Desain penelitian } \text { adalah } \\
\text { eksperimental semu dengan } \\
\text { one group pretest-posttest } \\
\text { design }\end{array}$ & $\begin{array}{l}\text { Hasil penelitian menunjukkan ada } \\
\text { penagruh terapi musik klasik mozart } \\
\text { terhadap kualitas tidur pada pasien } \\
\text { stroke di Pantiwilasa Citarum Semarang }\end{array}$ \\
\hline $\begin{array}{lr}\text { Nidaul Muflikah; } & \text { Upaya } \\
\text { Meningkatkan } & \text { Kualitas } \\
\text { Tidur Melalui Terapi Musik } \\
\text { Jawa Pada } & \text { Asuhan } \\
\text { Keperawatan } & \text { Gerontik; } \\
2019 & \\
\end{array}$ & $\begin{array}{l}\text { Desain penelitian dengan } \\
\text { menggunakan studi kasus }\end{array}$ & $\begin{array}{l}\text { Hasil penelitian diperoleh bahwa terapi } \\
\text { musik jawa dapat meningkatkan kualitas } \\
\text { tidur lansia }\end{array}$ \\
\hline $\begin{array}{l}\text { Nia Wahyu Marlina; } \\
\text { Efektivitas Terapi Murotal } \\
\text { Al-Quran Secara Audio } \\
\text { Visual terhadap Kualitas } \\
\text { Tidur Lansia dengan } \\
\text { Imsomnia di Panti Wredha } \\
\text { Budhi Dharma Umbulharjo } \\
\text { Yogyakarta; } 2019\end{array}$ & $\begin{array}{l}\text { Desain } \\
\text { eksperimental semu dengan } \\
\text { pretest-posttest with control } \\
\text { group design }\end{array}$ & $\begin{array}{l}\text { Hasil uji Wilcoxon Matched Pairs } \\
\text { diperoleh bahwa murottal Al-Quran efektif } \\
\text { untuk meningkatkan kualitas tidur pada } \\
\text { lansia }\end{array}$ \\
\hline
\end{tabular}

Sumber : Jurnal Lisna Agustina Medistra

\section{PEMBAHASAN}

Penelitian literature review ini bertujuan untuk menjelaskan bagaimana variabel terapi nonfarmakologis mempengaruhi kualitas tidur pada lansia. Kualitas hidup yang baik berkaitan dengan beragam hasil yang positif seperti kesehatan yang lebih baik, rasa kantuk yang lebih sedikit di siang hari, manusia yang lebih baik dengan fungsi psikologis yang lebih sempurna.
Permasalahan yang paling umum terjadi berkenaan dengan penuaan adalah masalah kualitas tidur; lebih dari setengah populasi lansia menderita kualitas tidur yang buruk. Tidur adalah salah satu dari empat dasar penting kehidupan yaitu air, udara, dan makanan.

Sebuah Lembaga Nasional yang meneliti masalah penuaan pada lebih dari 9000 orang berusia 65 tahun ke atas mengungkapkan bahwa dari satu setengah pria dan wanita 
dilaporkan setidaknya satu orang mengeluhkan masalah tidur yang kronis. Gejala-gejala dari masalah tidur pada lansia diantaranya adalah kesulitan tidur dan menjaga tidur, bangun dini hari dan rasa kantuk yang berlebihan di siang hari. Berbagai proses dapat mengganggu waktu tidur dan waktu bangun pada lansia. Diantaranya adalah penyakit medis yang akut dan kronis, efek pengobatan, gangguan psikiatrik, gangguan tidur primer, perubahan sosial, kebiasaan tidur yang buruk dan pergantian ritme sirkadian. Konsekuensi-konsekuensi dari permasalahan tidur yang kronis cukup besar. Kehilangan waktu tidur atau penggunaan obat penenang yang kronis yang dapat menyebabkan terjadinya jatuh atau kecelakaan. Penyembuhan secara nonfarmakologis terhadap gangguan tidur sangat diperlukan untuk meminimalkan efek terapi farmakologis Secara keseluruhan dari artikel penelitian yang dilskuksn menunjukkan bahwa teraoi nonfarmakologis yang diberikan pada lansia baik dengan gangguan tidur karena penyakit yang diderita maupun tidak dapat meningkatkan kualitas tidur lansia. Ini berarti pemilihan terapi nonfarmakologis bagi lansia dapat dilakukan, baik dengan terapi senam, musik, ataupun aromaterapi lavender. Terapi nonfarmakologis dapat meminimalkan ganggua tidur yang dialami oleh lansia. Tetapi perlu diingat juga bahwa terapi nonfarmakologis yang diberikan kepada lansia harus sesuai dengan keadaan dan kondisi lansia, misalnya kepercayaan, agama, suku, maupun penyakit yang diderita oleh lansia.

Salah satu terapi nonfarmakologis adalah senam lansia. Senam lansia yang teratur dapat meningkatkan kualotas tidur, karena senam berguna untuk mempertahankan dan memperbaiki kesegaran jasmani. Senam lansia dilakukan sedikitnya satu minggu sekalu dan sebanyakbanyaknya lima kali dalam satu minggu dengan lamanya 15 menit. Latihan fisik dapat meningkatkan relaksasi sehingga meningkatkan kebutuhan akan istirahat. Senam lansi secara rutin mamou meningkatkan konsumsi energi, sekresiendorfin, dan suhu tubuh yang dapat memfasilitasi tidur dalam proses penyembuhan tubuh. Aliran darah yang lancar mampu membuat transport darah ke otak lancar sehingga dapat mengontrol tekanan darah. Hal ini dapat meningkatkan kenyamanan lansia saat tidur. Tidur dipengaruhi oleh irama sirkardian dari detak jantung dan tekanan darah yang berasal dari penurunan saraf simpatis dan peningkatan saraf parasimpatis. Senam lanisa yang dilakukan rutin dapat meningkatkan saraf parasimpatis saat tidur, sehingga menurunkan tekanan darah dan meningkatkan kualitas tidur.

Terapi nonfarmakologis lain seperti terapi musik juga dapat meningkatkan kualitas tidur lansia karena musik diberikan untuk meningkatkan, mempertahankan dan mengembalikan kesehatan mental, fisik, emosional, dan spiritual seseorang. Terapi musik termasuk dalam terapi pelengkap (complementary therapy), dimana terapi musik sebagai teknik yang digunakan untuk penyembuhan suatu penyakit dengan menggunakan bunyi atau irama tertentu. Jenis musik yang digunakan, instrumentalia dalam terapi musik dapat dissuaikan dengan keinginan, seperti musik klasik, slow musik, orkestra, dan musik modern lainnya. Musik lembut dan teratur seperti instrumentalia dan musik klasik merupakan musik yang digunakan untuk terapi musik (djihan, 2006, hlm. 54). Penelitian Karmini (2007) tentang pengaruh pemberian terapi musik klasik terhadap gangguan tidur pada lansia di RS Telogirejo Semarang, ada pengaruh yang signifikan antara pemberian terapi musik dengan penurunan gangguan tidur pada lansia juga di ruang rawat inap RS Telogorejo Semarang. Musik memiliki aspek teurapetik, sehingga musik banyak digunakan untuk penyembuhan, menenangkan, dan memperbaiki kondisi fisik dan fisiologis pasien maupun tenaga kesehatan, karena berdasarkan penelitian ditemukan bahwa saraf penerus musik dan saraf penerus rasa sakit adalah sama, sehingga para dokter menggunakan musik sebagai terapi (Musbikin, 2009, dalam Mahanani, 2013, hlm1-4), sedangkan terapi nonfarmakologis yang lain seperti terapi tawa dan terapi relaksasi benson pada dasarnya 
memiliki cara kerja yang sama seperti terapi diatas yaitu memberikan efek relaksasi agar dapat meningkatkan kualitas tidur.

Terapi selanjutnya adalah dengan menggunakan aromaterapi bunga lavender diberikan kepada lansia yang memiliki gangguan tidur dengan memanaskan essential oil bunga lavender yang dipanaskan dengan tungku pemanas dan diberikan selama 7 hari berturut-turut. Aromaterapi memiliki kandungan utama yaitu linalil asetat yaitu suatu senyawa yang memiliki efek sedatif dan anti neuro depresif yang mampu mengendorkan dan melemaskan sistem kerja uratOurat saraf dan otot-otot tegang. Melalui inhalasi linalil asetat yang terkandung akan dibawa ke puncak hidung. Rambut getar yang ada didalamnya berfungsi sebagai reseptor, akan menghantarkan pesan aroma ke pusat emosi dan daya ingat seseorang yang selanjutnya akan mengantarkan pesan balik keseluruh tubuh melalui sistem sirkulasi. Pesan yang diantar keseluruh tubuh akan dikonfeksikan menjadi satu aksi pelepasan substansi neuri kimia berupa perasaan senang, rileks ataupun tenang. Bau yang menimbulkan rileks akan merangsang otak untuk mensekresi serotonin (hormon pemberi rasa nyaman dan senang) yang mengantarkan seseorang untuk tidur.

\section{KESIMPULAN}

Terapi nonfarmakologis adalah terapi pelengkap untuk meningkatkan kualitas tidur lansia. Terapi nonfarmakologis dipilih sebagai alternatif mengatasi gangguan tidur lansia dan meningkatkan kualitas tidur lansia karena dapat meminimalkan efek yang timbul dibandingkan dengan penggunaan terapi farmakologis dengan obat-obatan sedatif. Hal ini dikarenakan semakin meningkat usia semakin pula menurun sistem metabolisme tubuh seseorang. Selain itu kemampuan tubuh lansia yang sudah menurun dan proses degeneratif merupakan alasan penting dalam menggunakan terapi nonfarmakologis.

Terapi nonfarmakologis dapat meningkatkan kualitas tidur lansia, namun demikian kualitas tidur lansia dipengaruhi oleh faktor internal dan eksternal. Faktor internal yaitu keadaan fisik dan psikologis pada seseorang berbeda satu sama lain sehingga apabila terjadi perubahan fisik dan psikologis berupa adanya penyakit seperti hipertensi, gatal-gatal serta penyalit lainnya dan gangguan mood dapat mempengaruhi kualitas tidur seseorang. Begitu pula dengan faktor eksternal seperti perubahan lingkungan tempat tinggal, perubahan suhu ruangan tempat tidur, rutinitas lansia di siang hari dimana lansia jarang berkativitas seperti menonton tv dan tidur siang di siang hari menyebabkan lansia lebih mudah terbangun di tengah malam hari dan sulit untuk memulai tidur.

\section{SARAN}

Sebagai tenaga kesehatan terutama perawat baik yang ada di fasilitas pelayanan kesehatan maupun komunitas, menerapkan terapi farmakologis sebagai alternatif pilihan dalam mengatasi gangguan tidur pada lansia dan meningkatkan kualitas tidur merupakan pilihan tepat dibandingkan dengan terapi farmakologis. Namun demikian untuk memperbaiki dan dengan tepat pemilihan terapi nonfarmakologis perlu dilakukan penelitian selanjutnya dengan membandingkan terapi nonfarmakologis yang telah diteliti sebelumnya. Perbandingan tersebut harus sesuai dengan perlakukan yang diberikan kepada lansia misalnya membandingkan terapi dengan musik klasik dengan musik jawa atau membandingkan terapi tawa dengan terapi relaksasi benson dan sebagainya.

\section{DAFTAR PUSTAKA}

1. Annisa, E. (2013). The Prevalance of Sleep Disorder and Its Causes and Effects on Students Residing In Jahrom University of Medical Sciences Dormitories. Journal of Jahrom University of Medical Sciences 9(4):12- 16.

2. Arnot, dkk (2009). Pustaka Kesehatan Populer Pengobatan Praktis: Perawatan Alternatif dan Tradisional, volume 7. Jakarta: PT Bhuana IImu. 
3. Arysita,Putu (2013). Angka Kejadian Serta Faktor-Faktor Yang Mempengaruhi Gangguan Tidur (Insomnia) Pada Lansia Di Panti Sosial Tresna Werdha Seraya Denpasar Bali. Journal Studies.

4. Azizah, L. M. (2011). Keperawatanlanjutusia. Yogyakarta: grahailmu.

5. Bandiyah, S. (2009). Lanjut Usia dan Keperawatan Gerontik. Yogyakarta: Nuha Medika.

6. Baker et all (2013). Sleep Quality and The Sleep Electroenchephalogram. 1283-1291.

7. Buysse, D.J.,et al (1989). The Pittsburgh Sleep Quality Index (PSQI): A new Instrument for Psychiatric Practiceand Research, Pittsburgh: Elsevier Scientific Publishers Ireland Ltd.

8. Caple \& Grose. (2011). Sleep and Hozpitalization. Evidence-Basec Care Sheet. Sleep and Hozpitalization . Cinah Information System.

9. Darmojo, Boedhi, dan Martono, Hadi. Buku Ajar Geriatri (IImu Kesehatan Usia Lanjut) Edisi 2. 2000. Balai Penerbit FKUI. Jakarta.

10. Hidayat, A. (2008). Pengantar Kebutuhan Dasar Manusia: Aplikasi, Konsep dan Proses Keperawatan. Jakarta: Salemba Medika.

11. Hidayat, Alimul A. (2010). Metode Penelitian Kesehatan Paradigma Kuantitatif. Jakarta: Health Books.

12. Ibrahim, A. (2013). Sejahtera di Usia Senja:Dimensi Psikoreligi Pada Lanjut Usia. Jakarta.FKUI

13. Koensoemardiyah.(2009) $A-Z$ Aromaterapi untuk Kesehatan, Kebugaran, dan kecantikan. Yogyakarta:ANDI

14. Luo.J. Zhu G, Zhao Q/,Meng H/, Zhen $\mathrm{H}$,et al. Prevalen and risk factors of poor Sleep/ Quality among Chinese Elderly in an Urban Comunity : Result from Shanghai, Anging Study. Plos ONE 2013; 8 (11): e81261

15. Mau, (2012). Pengaruhpenerapanrelaksasib ensonterhadapgangguantidur

(insomnia padalansia di UPT PantiPenyantunanLanjutUsia Budi AgungKupang).

StikesmaranathaKupang.

16. Modjod, D. 2007. Insomnia Experience, Management Strategies, and Outcomes in ESRD Patients Undergoing Hemodialysis [Tesis].Mahidol University.

17. Nugroho, Wahjudi. (2008). Keperawatan Gerontik \& Geriatrik Edisi 3.EGC:Jakarta.

18. Nursalam. (2016). Metodologi Penelitian IImu Keperawatan Edisi 4.Jakarta: Salemba Medika.

19. Oscar primadi,PusatInformasidan data Kemenkes ,2013) dalambulletin kesehatanLansia

20. Ouellet, M.T.N. 1995. Sleep Satisfaction of Older Adult Living in the Community and Related Factors [Tesis]. Case Western Reserve University, Frances.

21. Rohmawati, Z. (2012). Korelasi Antara Frekuensi Senam Lansia Dengan Kualitas Tidur Pada Lanjut Usia Di Panti Sosial Tresna Werdha Unit Budi Luhur Yogyakarta Tahun 2012. Skripsi Dipublikasikan. Program Studi IImu Keperawatan Yogyakarta. 